\title{
Seedling Die-back of Dalbergia latifolia in Central India caused by Colletotrichum capsici - A New Record
}

\author{
Poonam Verma $^{1 *}$, K.K. Soni ${ }^{1}$, R.K. Verma ${ }^{1}$ and Fatima Shirin ${ }^{2}$ \\ Forest Pathology Division ${ }^{1}$, Genetics and Plant Propagation Division ${ }^{2}$, \\ Tropical Forest Research Institute, Jabalpur - 482 021, Madhya Pradesh, India \\ *Corresponding author
}

A B S T R A C T

\begin{tabular}{l} 
Key w o r d s \\
Dalbergia latifolia, \\
nursery disease, \\
seedling die back, \\
Ridomil. \\
\hline Article Info \\
\hline Accepted: \\
15 May 2016 \\
Available Online: \\
10 June 2016
\end{tabular}

\section{Keywords} albergia latifolia, Ridomil

Article Info

15 May 2016

10 June 2016
A new seedling die-back disease of Dalbergia latifolia was observed at Jabalpur in Central India. The causal organism was identified as Colletotrichum capsici. In nursery the disease ranges from 16.7 to $33.3 \%$ with an average of $25.2 \%$. To control the disease fungicide, $0.2 \%$ Ridomil Gold was applied at fortnightly interval as soil drench. The watering schedule was also monitored to avoid extra moisture in and around root zone of seedlings.

\section{Introduction}

Dalbergia latifolia Roxb. (syn. Dalbergia emarginata Roxb.) commonly known as blackwood, rosewood, Indian palisandre and Java palisandre is an economically important timber species native to lowelevation tropical monsoon forests of eastern India. Indian rosewood is reported to be scattered in the dry deciduous forest throughout the Indian peninsula. It grows in the sub-Himalayan tract from Oudh eastwards to Sikkim, Bihar, Orissa, and throughout Central and Southern India. Optimum growing conditions for this species are reported to be in the Bombay region (Troup and Joshi, 1983; Orwa et al., 2009). It is also used in apiculture because its honey is dark amber and strong flavored.
The wood is fragrant, very hard and difficult to work because of its high density. The heartwood is rated as very durable and is generally highly resistant to attack by termites and decay fungi (Orwa et al., 2009; NFTA, 1994). The sapwood, however, is liable to powder-post beetle attack. It is used to make premium-grade furniture, paneling, veneers and interior and exterior joinery. Secondary uses of the wood include knife handles, musical instruments, agricultural implements calico-printing blocks, mathematical instruments and boat keels and screws. Medicines made from the bark tannins are used against diarrhoea, worms, indigestion, leprosy and as appetizer (Kirtikar and Basu, 2005; Mohammad 
Khalid and Siddiqui, 2011; Rao Konda et al., 2013). It is planted as a shade tree in coffee plantations and on roadsides; being a nitrogen fixing tree and slow leaf litter decomposition it is used as mulch in crop production and also intercropped with annual crops or fruit tree (Khalid et al., 2011; Nadkarni, 1954).

For large scale plantation, seedlings of Dalbergia latifolia are raised in nurseries. The seedlings are raised in nursery beds as well as in polyethylene containers suffered from many disease (Sehgal, 1983) causing mortality and affecting the health and vigorous of plants (Harsh et al., 1992). Recently some wilt diseases of forest tree species caused by Fusarium solani are reported from this Institute for example, Litsea glutinosa (Verma and Verma, 2015); Pterocarpus marsupium (Verma and Verma, 2015a); and Madhuca indica (Verma et al., 2015).

In Dalbergia latifolia many diseases were recorded for example, leaf spot by Cercospora dalbergiae-latifoliae Chiddarwar from Pune, MS (Chiddarwar, 1959); Phyllachora dalbergiae Niessl from Coimbatore, TN (Hosagoudar, 1985a); Uromyces achorus Std. from Idukki, Kerala (Hosagoudar, 1985b). Colletotrichum capsici was recorded on 42 different vegetables, ornamental, flower plants and some forest tree species viz. Butea monosperma, Grewia oppositifolia, Jatropha gossypifolia, Mangifera indica, Manihot vtilissima, Prosopis juliflora, Rauwolfia serpentine, Sesbania grandiflora and Tabernaemontana divaricata tree (Bilgrami et al., 1981). The die back disease causes significant damage to young plantations (1-5years) (Verma et al., 1997) in Central India. An account of diseases of leguminous trees and their management has been reported (Verma et al., 2011) without any mention of die back disease Dalbergia latifolia by Colletotrichum capsici.

The present study reports a new record of seedling die back disease of Dalbergia latifolia caused by Colletotrichum capsici (Syd.) E.J. Butler and Bisby, in nursery of Central India.

\section{Materials and Methods}

\section{Study Area and Sample Collection}

The samples were collected from nursery of Genetics and Plant Propagation Division, Tropical Forest Research Institute (TFRI), Jabalpur, India is situated between $23^{\circ} 5^{\prime} 37^{\prime \prime}$ to $23^{\circ} 6^{\prime} 10^{\prime \prime} \mathrm{N}$ latitude and $79^{\circ} 59^{\prime} 49^{\prime \prime}$ to $79^{\circ} 59^{\prime} 42^{\prime \prime} \mathrm{E}$ longitude, average elevation is 411 meter from sea level. The area falls under basaltic landscape and the soil texture is more than $55 \%$ clay content. The soil of Jabalpur is black cotton soil. The temperature of Jabalpur varies from $9^{\circ} \mathrm{C}$ to $43^{\circ} \mathrm{C}$ and the average annual rainfall over the area is $1358 \mathrm{~mm}$ (Totey and Gupta, 1993). Dalbergia latifolia seeds were collected from TFRI campus and seedlings were raised in polyethylene bags. These seedlings were kept in groups under agroshade house and irrigated with sprinkler misting system. Numbers of disease in seedlings in each row were counted and recorded.

\section{Identification of Pathogen}

Diagnosis and identification of causal organism were done in laboratory. The pathogen was cultured in perti-dish using sterilized potato dextrose agar (PDA) medium inoculated with surface sterilized diseased bits of tender roots. After 5 days of incubation at $28 \pm 2{ }^{\circ} \mathrm{C}$, whitish wooly growth of fungal colony appeared in petri dish. For microscopic study, slides were 
prepared in lactophenol and cotton blue staining reagent and studied under different magnification using advance research microscope [Leica (Germany) model DMRB 1994] and photographs were taken. The infected sample is deposited in the forest pathology herbarium under Acc. No 3840 and culture is deposit in TFRI, Jabalpur under Acc. No. TFC 60. The pathogen was identified after cultural and microscopic study by consulting literature (Burnett, 1976; Jamaluddin et al., 2004; Verma et al., 2008; Nagmani et al., 2009).

\section{Disease Incidence}

Numbers of infected seedlings from each row of nursery were counted. Percentage disease incidence was determined as follows:

\begin{tabular}{|c|c|}
\hline Disease & $\begin{array}{l}\text { Number of seedlings } \\
\text { infected } \times 100\end{array}$ \\
\hline Incidence $\%=$ & $\begin{array}{l}\text { Total number of } \\
\text { seedlings }\end{array}$ \\
\hline
\end{tabular}

\section{Results and Discussion}

\section{Pathogen}

Colletotrichum capsici (Syd.) E.J. Butler and Bisby = Vermicularia capsici Syd. = Steirochaete capsici (Syd.) Sacc., Fungi of India: 152 (1931) (Fungi, Ascomycota, Pezizomycotina, Sordariomycetes, Glomerellales, Glomerellaceae)

The causal organism of Dalbergia latifolia seedling's die back was identified as follows:

Colonies with dense whitish to dark grey aerial mycelium; reverse dark brown, fruiting bodies acervuli, developing from the stromatic mass of hyphae, conidiophores closely packed, simple, short, hyaline; phialides in palisade layer; conidia aseptate, fusoid, somewhat curved or sickle shaped or cylindrical, smooth, 1-celled hyaline, aggregated in cream, orange or red or brownish sliny masses, appearing as glistening mass, conidial masses pale buff to salmon; sclerotia absent; setal abundant, long, rigid, bristle like, septate, dark below, lighter above; conidia falcate, fusiform, apices acute, 16-21 x 2.8-3.5 $\mu \mathrm{m}$.

\section{Pathogenicity test}

The pathogenicity was proved as per Koch's postulates by inoculating the healthy seedlings with fungal spore suspension. The spore suspension of pathogen was prepared $\left(4 \times 10^{3} \mathrm{cfu} / \mathrm{ml}\right)$ from $15 \mathrm{~d}$-old culture and 30 $\mathrm{ml}$ of spore suspension was inoculated in healthy plants (18 seedlings) having 5.5-8.5 $\mathrm{cm}$ height. The same pathogen was reisolated from inoculated affected seedlings in pure form and identified as $C$. capsici.

\section{Occurrence of Disease}

The disease appeared after the early rainfall in late July and continued up to September. The infected plants started dying from top to downward. Plant became partially to completely dry. The occurrence of the disease was calculated after counting the numbers of die back disease affected seedlings. Total 30 seedlings were observed in each row and number of affected seedling was counted. Disease ranges from 16.7 to $33.3 \%$ with an average of $25.2 \%$ (Table 1 ). The pathogens produced large number of viable conidia in nursery, thereby, causing severe damage to the seedlings.

\section{Management of Disease}

To manage the disease fungicide, $0.2 \%$ Ridomil Gold, (Make, Syngenta, containing metalaxyl-M, 4\%, mancozeb, $64 \%$, sodium lignosulfunate, $2 \%$ and dibutylnaphthalene sulfonic acid sodium salt, 2\%) was applied 
at fortnightly interval as soil drench. The watering schedule was also monitored to avoid extra moisture in and around root zone of seedlings. The above treatments and management practice control the disease up to $93.69 \%$.

Sapling die-back in young plantation was also reported in Acacia nilotica, Albizia lebbeck and Pongamia pinnata with mortality percentage $25.5 \%, 20.8 \%$ and $11.3 \%$, respectively caused by
Haplosporella bakeriana and $H$. beaumontiana (Verma et al., 1997) but they have not applied any management method to control the disease. Gupta et al. (1997) observed die back in mulberry at different locations in Karnataka and Andhra Pradesh. Botryodiplodia theobromae was isolated as causal organism. Greennhalgh (1981) reported Collectotrichum gloeosporioides dieback disease of many species of the genus Protea in Australia.

Table.1 Occurrence of seedling die back disease in nursery

\begin{tabular}{|c|c|c|c|c|}
\hline $\begin{array}{c}\text { Row } \\
\text { No. }\end{array}$ & $\begin{array}{c}\text { Total number of } \\
\text { seedlings } \\
\text { examined }\end{array}$ & $\begin{array}{c}\text { Die back affected } \\
\text { seedlings }\end{array}$ & Disease \% & $\begin{array}{c}\text { Control of disease } \\
\text { after management } \\
(\boldsymbol{\%})\end{array}$ \\
\hline 1 & 30 & 10 & 33.3 & 83.3 \\
\hline 2 & 30 & 5 & 16.7 & 100 \\
\hline 3 & 30 & 8 & 26.7 & 93.3 \\
\hline 4 & 30 & 6 & 20 & 96.67 \\
\hline 5 & 30 & 12 & 40 & 80 \\
\hline 6 & 30 & 7 & 23.33 & 96.67 \\
\hline 7 & 30 & 5 & 16.7 & 93.3 \\
\hline 8 & 30 & 7 & 23.33 & 100 \\
\hline 9 & 30 & 8 & 26.7 & $\mathbf{9 3 . 6 9}$ \\
\hline Avg. & $\mathbf{3 0}$ & $\mathbf{7 . 5 5}$ & $\mathbf{2 5 . 2}$ & \\
\hline
\end{tabular}

Fig.A-E Colletotrichum capsici (A) affected seedlings of Dalbergia latifolia showing symptoms (B) pure culture on PDA (C-E) acervulus with prominent setae and conidium
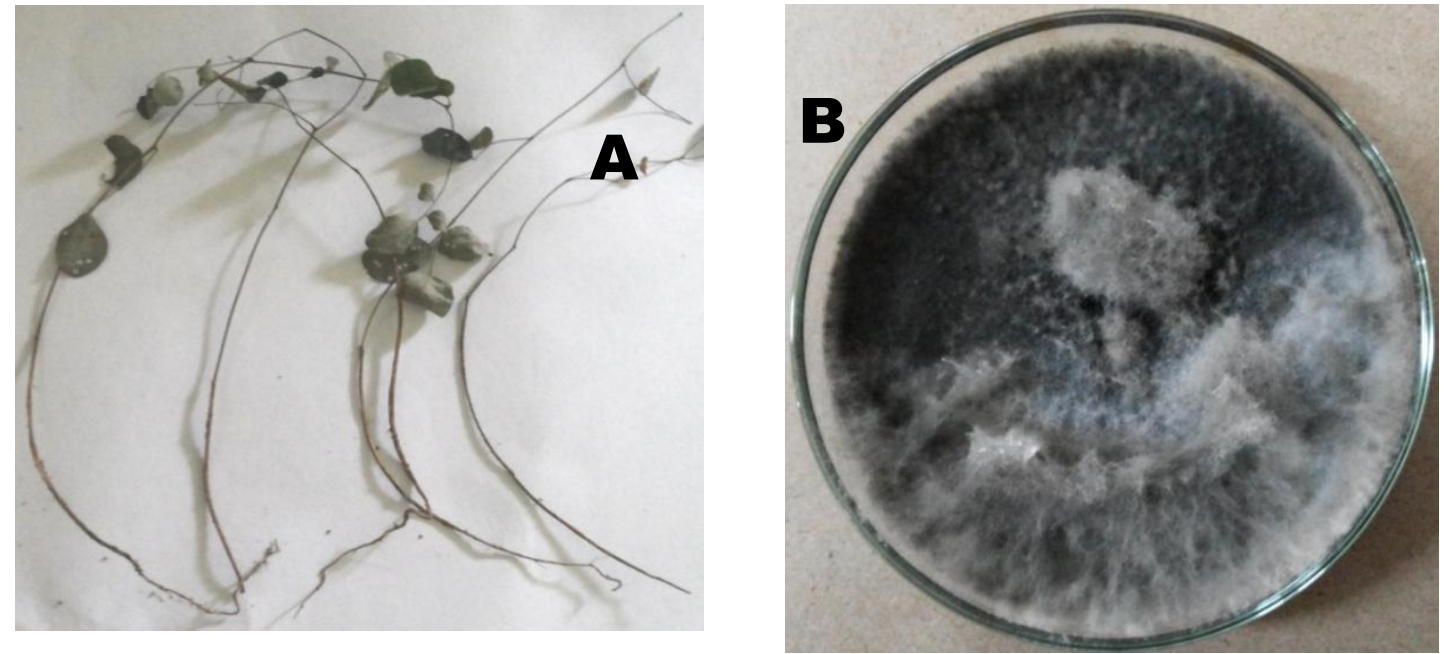


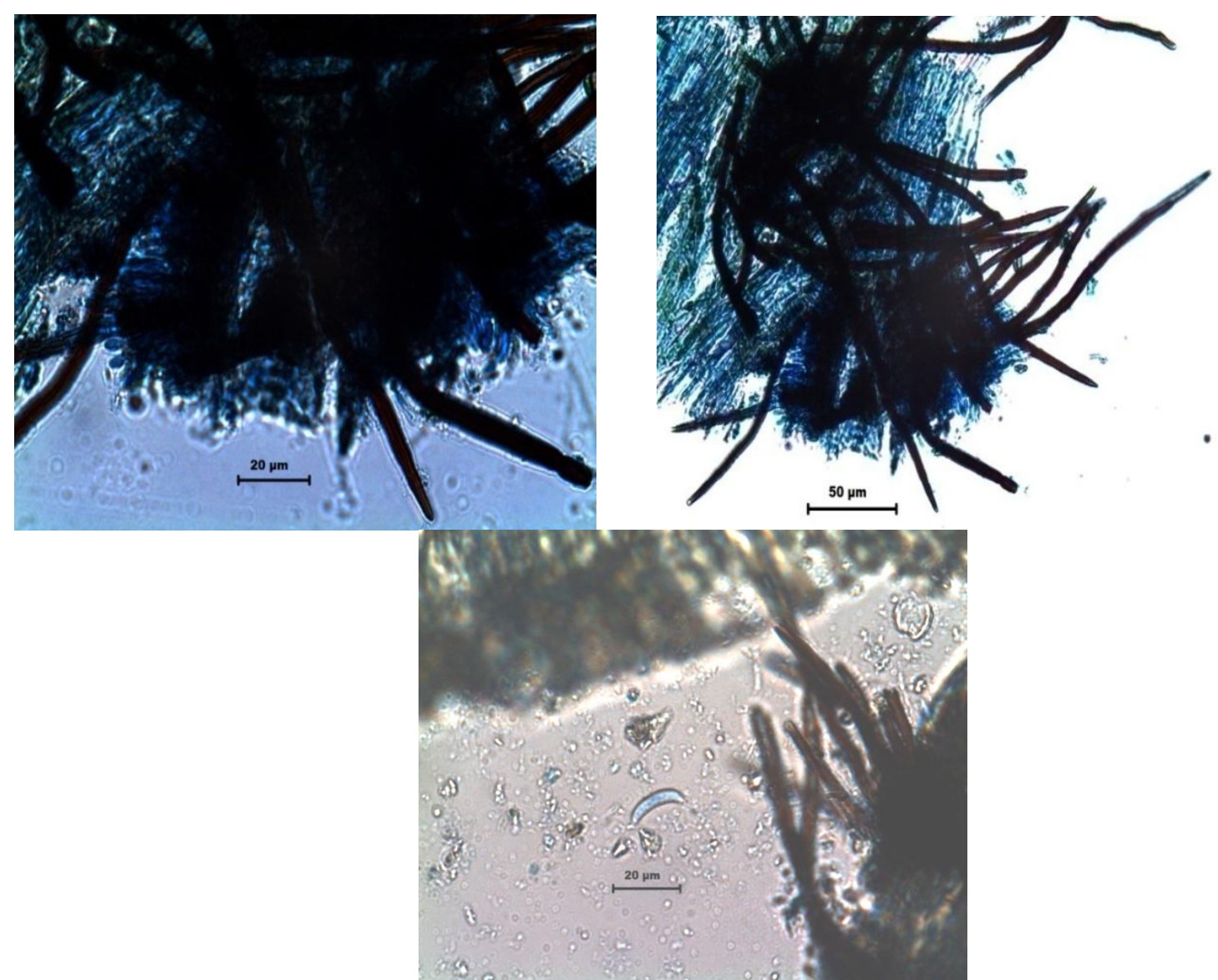

Similar result was found in South Africa nurseries by Benić and Knox-Davies, (1983) and disease was completely cured by using chemical fungicide. Dalbergia latifolia, being an important tree species therefore in the present study, its die back disease was controlled by application of chemical fungicide. Solano and Arauz, (1995) applied 5 fungicides against papaya anthracnose caused by Colletotrichum gloeosporioides and found that mancozeb and prochloraz showed the best result. Freeman et al. (1997) also assessed various fungicides like folpet, captan and propaconazole to control this pathogen and found captan at $50 \%$ was the most effective. Dubey and Ekka (2003) tried 13 fungicides to control blight disease of bitter gourd (Momordica charantia L.) by Colletotrichum capsici and amongst fungicides tried, Topsin $\mathrm{M}$ gave the best result.
$\mathbf{E}$

Combination of bio-control agent, Trichoderma and fungicides showed good results for control of Colletotrichum (Freeman et al., 2004). Hussain et al. (2008) also used Trichoderma spp. and fungicide in different conc., and reported that mancozeb is the most effective against the pathogen. Five isolates of Trichoderma viride and two isolates of Beauveria bassiana were screened against Colletotrichum gloeosporioides for their antagonistic potentiality by dual culture plate method. Three isolates of $T$. viride and one isolate of Beauveria bassiana were found effective bio-control agents against anthracnose of sarpagandha (Rauvolfia serpentina) (Ghosh and Chakraborty, 2012).

In conclusion, a seedling disease of Dalbergia latifolia caused by Colletotrichum capsici is reported from the 
first time from Central India. Incidence of the disease varies from 16.7 to $33.3 \%$. The disease can be controlled by application of $0.2 \%$ fungicide, Ridomil and avoiding extra moisture in root zone of seedlings in nursery conditions.

\section{Acknowledgement}

Authors are thankful to Dr. U. Prakasham, Director, Tropical Forest Research Institute, Jabalpur for providing laboratory facilities and Head, Genetics and Plant Propagation Division for providing the seedlings for study.

\section{References}

Benic, L.M., Knox-Davies, P.S. 1983. Anthracnose of Protea compacta caused by Collectotrichum gloeosporioides. Phytophylactica, 15: 109-119.

Bilgrami, K.S., Jamaluddin, Rizwi M.S. 1981. Fungi of India - List and Reference, part I and II, Today and Tomorrow's Prints and Publishers, New Delhi, pp 798.

Burnett, J.H. 1976. Fundamentals of mycology. 2nd ed. London, United Kingdom: Arnold.

Chiddarwar, P.P. 1959. Contribution to our knowledge of the Cerocporae of Bombay State-I. Sydowia, 13: 152-163.

Dubey, S.C., Ekka, S. 2003. Integrated chemical management of Colletotrichum blight of bitter gourd. Indian Phytopath., 56(2): 218-220.

Freeman, S., Minz, D., Kolesnik, I., Barbul, O., Zveibil, A., Maymon, M., Nitzani, Y., Kirshner, B., Rav-David, D., Bilu, A., Dag, A., Shafir, S., Elad, Y. 2004. Trichoderma biocontrol of Colletotrichum acutatum and Botrytis cinerea and survival in strawberry. Eur.J. Plant Pathol., 110: 361-370.

Freeman, S., Nizani, Y., Dtatan, S., Even, S., Sando, T. 1997. Control of
Colletotrichum acutatum in strawberry under lab, green house and field conditions. Plant Dis., 81: 749-752.

Ghosh, S.K., Chakraborty, N. 2012. In vitro biological control of Colletotrichum gloeosporioides, causal organism of anthracnose of sarpagandha (Roulvolfia serpentina). Agric. Biol. J. N. Am., 3(8): 306-310.

Greenhalgh, F.C. 1981. Diseases of Proteaceous Plants. In: Growing and Marketing of Proteas. P. Mathews, eds. Pp 30-39. Proteaflora Enterprizes, Melbourne.

Gupta, V.P., Govindaiah, Raju, H.V. 1997. Disease and associated fungal pathogens of mulberry nurseries. Indian Phytopathol., 50(3): 402-407.

Harsh, N.S.K., Dadwal, V.S., Jamaluddin. 1992. A new post emergence damping off disease of Eucalyptus seedling. Indian For., 118: 279-283.

Hosagoudar, V.B. 1985a. New and notworthly species of Phyllachora from South India. India Phytoapth., 38: 447451.

Hosagoudar, V.B. 1985b. Teliomycetes of south India. India Phytoapth., 38: 278281.

Hussain, A., Raziq, F., Khan, H. 2008. In vitro integrated control of Colletotrichum gloeosporioides with biological and chemical agents. Sarhad J. Agric. 24(1): 79-84.

Jamaluddin, Goswami, M.G., Ojha, B.M. 2004. Fungi of India (1989-2001). Scientific Publisher, Jodhpur (India) 326p.

Khalid, M., Siddiqui, H.H., Sheeba, F. 2011. In-vitro Assessment of Antioxidant Activity of Dalbergia latifolia Barks Extract Against Free Radicals. AEJSR, 6(3): 172-177.

Kirtikar, K.R., Basu, B.D. 2005. Indian medicinal plants. International Book Distributor, Dehradun, India. pp, 824. 
Mohammad Khalid, Siddiqui, H.H. 2011. Lipid lowering and hypoglycaemic potential of dried Dalbergia latifolia Roxb. Bark extract in Sprague-Dawley rats induced with high fat diets. Int. J. Appl. Res. Nat. Prod., 1(4): 49-54.

Nadkarni, K.M. 1954. Indian material Medica. $3^{\text {rd }}$ edition, Bombay, Popular book depot, pp, 432.

Nagmani, A., Kunwar, I.K., Manoharachary, C. 2006. Hand book of soil fungi: In International Pvt. Ltd. New Delhi, 477p.

NFTA. 1994. Dalbergia latifolia: a highvalued Indian rosewood. NFTA 94-04. Waimanalo.

Orwa, C., Mutua, A., Kindt, R., Jamnadass, R., Simons, A. 2009. Agroforest tree Database: a tree reference and selection guide version 4.0.

Rao Konda, V.G., Madhavi, E., Ruckmani, A., Venkataramana, Y. 2013. A review on medicinal plants with potential hypolipidemic activity. Int. J. Pharm. Biol. Sci., 4(4): 729 - 740.

Sehgal, H.S. 1983. Disease problem of Eucalyptus in India. Indian For., 109: 909-816.

Solano, V., Arauz, L.F. 1995. Combating anthracnose in papaya fruit through fungicide application in Atlantic region of Costa Rica. Agronomia Costarricense, 19: 25-30.

Totey, N.G., Gupta, B.N. 1993. Soil of Barha experimental area, TFRI technical report No. 3 Tropical Forest Research Institute, Jabalpur, India.
Troup, R.S., Joshi, H.B. 1983. Troup's The Silviculture of Indian Trees. Vol IV. Leguminosae. Delhi, India.

Verma, P., Verma, R.K. 2015. A new wilt disease of maida chhal (Litsea glutinosa) in central India. World $J$. Pharm. R., 4(3): 1483-1491.

Verma, P., Shirin, F., Verma, R.K. 2015. Root-rot disease of Madhuca indica (mahua): A new record. IJCR, 7(6): 16751-16754.

Verma, R.K., Verma, P. 2015a. A new wilt and root rot disease of Pterocarpus marsupium in central India. World $J$. Pharm. R., 4(3): 1941-1947.

Verma, R.K., Jamaluddin, Soni, K.K. 1997. Die back of leguminous trees in young plantations caused by Haplosporella in Central India. My forester, 123(7): 652655.

Verma, R.K., Parihar, J., Tiwari, C.K. 2011. Diseases of leguminous trees and their management. Pp. 47-84. In: PC Trivedi (ed.) Plant Health Management. Agrobios (India), Jodhpur, Rajasthan $437 p$.

Verma, R.K., Sharma, N., Soni, K.K., Jamaluddin. 2008. Forest fungi of central India. International Book Distributing Co. Lucknow, 418p.

Yadav, S.K., Nagarathna, P.K.M., Yadav, C.K. 2015. Research article of evaluation of immunomodulatory activity of Dalbergia latifolia on Swis Albino Mice. JPBR, 10(1): 58-64.

\section{How to cite this article:}

Poonam Verma, K.K. Soni, R.K. Verma and Fatima Shirin. 2016. Seedling Die-back of Dalbergia latifolia in Central India caused by Colletotrichum capsici - A New Record. Int.J.Curr.Microbiol.App.Sci. 5(6): 350-356. doi: http://dx.doi.org/10.20546/ijcmas.2016.506.040 